\title{
PENGARUH PENGGUNAAN Sargassum sp. DAN TEPUNG TAPIOKA TERHADAP SIFAT SENSORI DAN KOMPOSISI PROKSIMAT PETIS KEPALA UDANG VANNAME (Litopenaeus vannamei)
}

Effect of Sargassum sp. and Tapioka Flour on The Properties of Sensory and Proximate of Shrimp Head Vaname (Litopenaeus vannamei) Paste

\section{Arniati Johan ${ }^{1 *}$, Asnani ${ }^{1}$, Sri Rejeki ${ }^{2}$}

1Jurusan Teknologi Hasil Perikanan, Fakultas Perikanan dan Ilmu Kelautan Universitas Halu Oleo, Kendari, Sulawesi Tenggara, Indonesia

2Jurusan IImu dan Teknologi Pangan, Fakultas Pertanian Universitas Halu Oleo, Kendari, Sulawesi Tenggara, Indonesia

*Email korespondensi: arniatijohan5@gmail.com (Telp: +6282339997202)

Diterima: 13 Januari/ Disetujui 20 Maret 2020

Cara sitasi: Johan A, Asnani, Rejeki S. 2020. Pengaruh penggunaan Sargassum sp. dan tepung tapioka terhadap sifat sensori dan komposisi proksimat petis kepala udang vanname (Litopenaeus vannamei). Jurnal Fish Protech. 3(1):133142.

\section{ABSTRACT}

Seaweed Sargassum sp. is not much utilized but has the potential as a manufacturing agent or stabiliser in the manufacture of petis. This research aims to determine the quality of paste from the head of shrimp Vaname that is made with a combination of filler material Sargassum sp. and tapioca flour with different concentrations. The study uses complete random design (RAL) with four treatment with the composition of shrimp head broth, tapioca starch and Sargasum $s p$ slurry. Consecutive: 90:10:0\% (P1), 90:2:8\% (P2), 90:4:6\% (P3), and 90:6:4\% (P4). The characteristics of the paste tested are sensory properties and proximate composition. The results showed $P 3$ treatment resulted in the best sensory value on the attribute of flavors with a value of 7.4 criteria dominant shrimp taste sweet and salty enough, the category is very fond. The value of water content is $29.86 \%$, ash content is $5.66 \%, 16.79 \%$ protein content, fat content is $0.21 \%$, carbohydrate content is $46.26 \%$ and fiber content is $1.12 \%$. Proximate content produced shrimp paste in accordance with SNI 01-23346-2006.

Keywords: tapioca flour, Sargassum sp., shrimp head Vannamei paste

\section{ABSTRAK}

Rumput laut jenis Sargassum sp. belum banyak dimanfaatkan padahal mempunyai potensi sebagai bahan pengental atau pengstabil dalam pembuatan petis. Penelitian ini bertujuan untuk mengetahui kualitas petis dari kepala udang Vaname yang dibuat dengan kombinasi bahan pengisi yaitu rumput laut Sargassum sp. dan tepung tapioka dengan konsentrasi yang berbeda. Penelitian ini menggunakan Rancangan Acak Lengkap (RAL) dengan empat perlakuan dengan komposisi kaldu kepala udang, tepung tapioka dan bubur Sargasum sp. berturut-turut: 90:10:0 \% (P1), 90:2:8 \% (P2), 90:4:6 \% (P3), dan 90:6:4 \% (P4). Karakteristik petis yang diuji yaitu sifat sensori dan komposisi proksimat. Hasil penelitian menunjukkan perlakuan $\mathrm{P} 3$ menghasilkan nilai sensori terbaik pada atribut rasa dengan nilai sebesar 7,4 kriteria rasa udang dominan manis dan asin cukup, kategori sangat suka. Nilai kadar air yaitu 29,86\%, kadar abu $5,66 \%$, kadar protein $16,79 \%$, kadar lemak 0,21\%, kadar karbohidrat $46,26 \%$ dan kadar serat 1,12\%. Kandungan proksimat petis yang dihasilkan sesuai SNI 01-23346-2006.

Kata kunci: Tepung tapioka, Sargassum sp., petis kepala udang Vanamei 


\section{PENDAHULUAN}

Udang Vaname merupakan salah satu makanan yang digemari oleh masyarakat, karena memiliki nilai gizi yang tinggi terutama protein sebanyak 18,1\% (Hafiz, 2009). Udang Vaname merupakan organisme akuatik asli pantai Pasifik Meksiko, Amerika Tengah dan Amerika Selatan, namun tumbuh dengan baik di Indonesia. Menurut Purwanti et al. (2014), indonesia sebagai negara penghasil udang terbesar ketiga di dunia. Setiap tahunnya dihasilkan sekitar 0,08 juta ton dari luas tambak udang 380.000 hektar. Adapun limbah udang yang dihasilkan dari proses pengolahan udang berkisar 30-40 persen dari berat udang.

Limbah udang merupakan hasil sampingan dari industri pengolahan udang daging berupa bagian kepala, cangkang dan udang kecil utuh yang tidak termanfaatkan (Gernat, 2001). Limbah udang berpotensi karena masih memiliki kandungan nutrisi yang tinggi dengan kandungan protein kasar sebesar 45-55\% (Khempaka et al., 2006). Kulit dan kepala udang Vaname memiliki kandungan air sebesar $10,12 \%$, pada kadar abu Kepala udang Vaname memiliki kandungan abu sebesar 27,59\%, dan kandungan lemak sebesr 2,65\%. (Pratiwi et al., 2017). Pemanfaatan limbah udang yang sudah berkembang di masyarakat adalah dengan cara mengolah limbah tersebut menjadi tepung kepala udang, yang selanjutnya digunakan sebagai bahan campuran pada pengolahan pakan udang atau ternak. Dalam jumlah yang lebih kecil kepala udang digunakan sebagai campuran pada pengolahan beberapa produk olahan tradisional seperti terasi, petis dan kerupuk (Saleh et al., 1994).

Sargassum sp. merupakan rumput laut yang termasuk dalam kelas Phaeophyceae. di Indonesia, Sargassum sp. memiliki sebaran yang luas dan bervariasi. Jenis rumput laut tersebut termasuk tumbuhan yang dominan dan terdistribusi di seluruh perairan Indonesia, antara lain di Selat Sunda, Perairan Bangka Belitung, Karimunjawa, Pantai Selatan Pulau Jawa, Pantai Bali, Pantai Lombok, Kupang, Kalimantan Timur, Sulawesi Tenggara, Sulawesi Utara, Ternate, Ambon, Teluk Lampung dan
Perairan Natuna (Kadi, 2005). Kandungan Sargassum sp. lainnya adalah alkaloida, fenol, dan triterpenoid yang berfungsi sebagai antibakteri, antivirus dan anti jamur, sehingga pemanfaatan Sargassum sp. dalam berbagai bidang berkembang pesat sebagai bahan makanan, bahan bakar (Fuels), kosmetik, obatobatan, serta bahan pakan tambahan (Muhklisani, 2018). Sargassum sp. berupa bahan pembentuk gel banyak digunakan industri makanan bukan sebagai penambah nilai gizi tetapi menghasilkan dan memperbaiki tekstur atau stabilitas dari produk olahan seperti permen jeli, es krim, sari buah, pastel isi dan kue-kue (Yunizal, 2004). Rumput laut Sargassum sp. mengandung alginat, pigmen coklat, serat, karbohidrat, lemak yang rendah, mineral, vitamin, dan asam-asam amino sehingga cocok dijadikan bahan pangan dan bermanfaat untuk kesehatan sehingga berpotensi digunakan pada produk petis udang.

Petis merupakan produk makanan semi basah berbentuk pasta yang merupakan hasil samping dari daging, ikan atau udang. Masyarakat indonesia khususnya pulau Jawa mengenal petis sebagai bumbu penyedap yang memberikan rasa khas pada makanan tradisional. Pada umumnya bahan baku pembuatan petis adalah limbah udang, ikan, atau daging (Firdaus et al., 2016). Ciri - ciri petis yang baik adalah berwarna cerah (tidak kusam), umumnya coklat kehitaman karena ada penambahan gula merah, pewarna buatan, ataupun cairan tinta cumi, berbau sedap, gurih, kental tetapi sedikit lebih encer dari margarin (Suprapti, 2001). Selain itu petis mempunyai tekstur yang halus dan mudah dioleskan (Astawan, 2004). Upaya yang dapat dilakukan adalah dengan menambahkan rumput laut Sargassum sp. sebagai bahan pengisi petis dan belum ada penelitian yang melaporkan penggunaan Sargassum sp. pada pembuatan petis udang. Tujuan penelitian ini adalah bagaimana pengaruh kombinasi penggunaan Sargassum sp. dan tepung tapioka terhadap kualitas petis udang secara kimia maupun organoleptik 


\section{Alat dan Bahan}

\section{METODE PENELITIAN}

Alat yang digunakan dalam penelitian ini ada 2 macam yaitu alat untuk pengolahan dan alat untuk analisis. Alat pengolahan meliputi: baskom, panic (Maximo Valentino), timbangan analitik, blender (Miyako), kompor gas (Rinnai), termometer dan stopwatch. Alat-alat yang digunakan dalam analisis . Alat untuk analisis kimia: gelas ukur (Pyrex), tabung reaksi (Pyrex), termometer, erlenmeyer, desikator, kapas, kondensor, labu destilasi, labu lemak, oven.

Bahan yang digunakan dalam penelitian ini adalah: rumput laut Sargassum sp. Bahan pendukungnya adalah tepung tapioka (Produksi Tirta kencana), gula aren, bawang putih, sereh dan air mineral. Bahan kimia untuk analisis kimia. Bahan untuk analisis kimia yaitu akuades, $\mathrm{HCl}, \mathrm{NaOH}, \mathrm{H}_{2} \mathrm{SO}_{4}$ pekat, $\mathrm{HNO}_{3}, \mathrm{H}_{3} \mathrm{BO}_{3}, \mathrm{~K}_{2} \mathrm{SO}_{4}$, methanol, pelarut heksana.

\section{Rancangan Penelitian}

Penelitian ini menggunakan Rancangan Acak Lengkap ( $R A L$ ) dengan empat perlakuan dengan komposisi kaldu kepala udang, tepung tapioka dan bubur Sargasum sp. berturut-turut: 90:10:0 \% (P1), 90:2:8 \% (P2), 90:4:6 \% (P3), dan 90:6:4 \% (P4). Karakteristik petis yang diuji yaitu sifat sensori dan komposisi proksimat. Masing-masing perlakuan 3 kali ulangan, sehingga diperoleh jumlah satuan percobaan sebanyak 12 unit.

\section{Pembuatan Petis Udang \\ Penyiapan Bahan Baku}

Penyiapan kepala udang meliputi: penimbangan $(1 \mathrm{~kg})$, pencucian dengan air mengalir sampai bersih, perebusan I untuk membersihkan dan perebusan II untuk mendapatkan kaldu kepala udang. Sedangkan penyiapan rumput Sargassum sp. meliputi: Penyiapan rumput laut penimbangan $(30 \mathrm{~g})$, pencucian dengan air mengalir sampai bersih, kemudian perendaman selama 24 jam menggunakan air cucian beras, dan diganti setiap 12 jam.

\section{Pembuatan Kaldu Kepala Udang}

Kepala udang direbus sebanyak dua kali perebusan. Perebusan pertama pada suhu $100^{\circ} \mathrm{C}$ dilakukan pemasakan kepala udang menggunakan air sebanyak $1000 \mathrm{ml}$ selama $80^{\circ} \mathrm{C}$ selama 2 jam untuk menghasikkan cairan sari atau kaldu kepala udang.

\section{Pembuatan Bubur Sargassum sp.}

Rumput laut Sargassum sp. yang telah direndam selama 24 jam dilanjutkan dengan proses penghalusan rumput laut Sargassum sp. menggunakan mesin penghancur (blender), dan menghasilkan bubur Sargassum sp.

\section{Parameter uji}

Pengujian yang dilakukan meliputi: Uji sensori petis (BSN-2006), Uji kadar air (AOAC, 2005) Uji kadar abu (AOAC, 2005) Uji kadar lemak (AOAC, 2005) Uji kadar protein (AOAC, 2005) Uji kadar serat kasar (AOAC, 2005) dan Analisi kadar karbohidrat (Winarno, 1996).

\section{Analisis Data}

Parameter yang akan diamati dilakukan analisis ragam ANOVA (Analysis of variance) dan jika terdapat pengaruh

antar perlakuan maka akan dilanjutkan dengan uji DMRT (Duncan multiple range test) pada tingkat kepercayaan 95\% ( $\alpha=0,05)$. Data diolah menggunakan aplikasi Microsoft Exel (2010), Penentuan perlakuan terpilih menggunakan metode Indeks Efektivitas (Garmo et al., 1984). 


\section{HASIL DAN PEMBAHASAN}

\section{Penilaian Sensori dan Hedonik}

\section{a. Kenampakan}

Tabel 1. Rerata hasil penilaian deskriptif pada parameter kenampakan petis udang

\begin{tabular}{clc}
\hline Perlakuan ${ }^{1)}$ & Rerata & Kategori \\
\hline P1 & $6,1 \pm 0,1^{\mathrm{a}}$ & 6 = coklat kehitaman agak kusam \\
P2 & $7,2 \pm 0,2^{\mathrm{c}}$ & 7 = coklat kehitaman agak cemerlang \\
P3 & $6,8 \pm 0,2^{\mathrm{b}}$ & \\
P4 & $6,4 \pm 0,1^{\mathrm{b}}$ & \\
\hline
\end{tabular}

Ket: 1) komposisi kaldu kepala udang, tepung tapioka dan bubur Sargasum sp. berturut-turut: 90:10:0 \% (P1), 90:2:8 \% (P2), 90:4:6 $\%$ (P3), dan 90:6:4 \% (P4); DMRT0,05: $2=0,254,3=0,264,4=0,274$

Tabel 2. Rerata hasil penilaian hedonik pada parameter kenampakan petis udang

\begin{tabular}{cccc}
\hline Perlakuan & Rerata \pm SD & Kategori & DMRT 0.05 \\
\hline P1 & $3,6 \pm 0,1^{\mathrm{a}}$ & Suka & \\
P2 & $4,2 \pm 0,2^{\mathrm{b}}$ & Suka & $2=0,163$ \\
P3 & $3,9 \pm 0,1^{\mathrm{b}}$ & Suka & $3=0,169$ \\
P4 & $3,7 \pm 0,1^{\mathrm{a}}$ & Suka & $4=0,173$
\end{tabular}

Ket: ${ }^{1)}$ komposisi kaldu kepala udang, tepung tapioka dan bubur sargasum sp. berturut-turut: 90:10:0 \% (P1), 90:2:8 \% (P2), 90:4:6 \% (P3), dan 90:6:4 \% (P4); DMRTo,05: $2=0,0,163,3=0,169,4=0,173$

Kenampakan merupakan karakteristik pertama yang dinilai oleh konsumen (Rochima, 2015). Hasil analisis ragam terhadap uji deskriptif nilai kenampakan petis udang menunjukkan nilai tetinggi pada perlakuan $\mathrm{P} 2$ sebesar 7,2 dengan kriteria coklat kehitaman agak cemerlang dan nilai terendah pada perlakuan P1 sebesar 6,1 dengan kriteria coklat kehitaman agak kusam. Hasil penilaian hedonik (Tabel 2) menunjukkan penggunaan Sargassum sp. berbanding lurus dengan tingkat kesukaan panelis terhadap kenampakan petis udang. Hasil Yunizal, 2004).

\section{b. Aroma}

Tabel 3. Rerata hasil penilaian deskriptif pada parameter aroma petis udang

\begin{tabular}{clc}
\hline Perlakuan & Rerata & Kategori \\
\hline P1 & $7,3 \pm 0,1^{\mathrm{c}}$ & $7=$ harum spesifik petis udang sangat kuat \\
P2 & $6,3 \pm 0,2^{\mathrm{a}}$ & $6=$ spesifik petis udang kurang \\
P3 & $6,8 \pm 0,1^{\mathrm{b}}$ & \\
P4 & $7,0 \pm 0,1^{\mathrm{b}}$ & \\
\hline
\end{tabular}

Ket: 1) komposisi kaldu kepala udang, tepung tapioka dan bubur Sargasum sp. berturut-turut: 90:10:0 \% (P1), 90:2:8 \% (P2), 90:4:6 $\%$ (P3), dan 90:6:4 \% (P4); DMRTo,05: $2=0,237,3=0,247,4=0,253$ 
Tabel 4. Rerata hasil penilaian hedonik pada parameter aroma petis udang

\begin{tabular}{cccc}
\hline Perlakuan & Rerata \pm SD & Kategori & DMRT 0.05 \\
\hline P1 & $4,5 \pm 0,2^{\mathrm{c}}$ & Sangat Suka & \\
P2 & $3,5 \pm 0,1^{\mathrm{a}}$ & Suka & $2=0,221$ \\
P3 & $3,7 \pm 0,1^{\mathrm{a}}$ & Suka & $3=0,230$ \\
P4 & $4,0 \pm 0,2^{\mathrm{b}}$ & Suka & $4=0,235$
\end{tabular}

Ket: 1) komposisi kaldu kepala udang, tepung tapioka dan bubur Sargasum sp. berturut-turut: 90:10:0 \% (P1), 90:2:8 \% (P2), 90:4:6 $\%$ (P3), dan 90:6:4 \% (P4); DMRT0,05: $2=0,221,3=0,230,4=0,235$

Aroma dapat didefinisikan sebagai sesuatu yang dapat diamati dengan indera pembau. (Kartika et al., 1998). Hasil uji deskriptif menunjukkan nilai rerata tertinggi pada perlakuan P1 sebesar 7,3 dengan harum spesifik petis udang sangat kuat dan nilai terendah terletak pada perlakuan P2 sebesar 6,3 dengan kriteria spesifik petis udang kurang. Hasil penilaian hedonik (Tabel 4) menunjukkan bahwa peningkatan konsentrasi Sargassum sp. berbanding terbalik dengan tingkat kesukaan panelis terhadap aroma petis udang. Hasil aroma petis penelitian ini berbeda dengan hasil penelitian Anwar (2013), menunjukan bahwa penambahan garam $10 \mathrm{~g}$ yaitu dengan kriteria spesifik petis udang kurang. Tingginya nilai kesukaan panelis dalam penelitian ini diduga dipengaruhi oleh jumlah proporsi tepung tapioka hal ini sesuai dengan pernyataan Rusmono (1983) dalam Sopyan (2012) yang menyatakan bahwa tepung merupakan senyawa yang tidak memiliki bau (netral) sehingga tepung tapioka tidak mengubah aroma khas petis.

\section{c. Tekstur}

Tabel 5. Rerata hasil penilaian deskriptif pada parameter tekstur petis udang

\begin{tabular}{clc}
\hline Perlakuan & Rerata & Kategori \\
\hline P1 & $7,3 \pm 0,3^{\mathrm{c}}$ & $7=$ kental homogen dan lembut \\
P2 & $5,9 \pm 0,4^{\mathrm{a}}$ & 6 = agak kental kurang homogen kasar \\
P3 & $6,3 \pm 0,1^{\mathrm{b}}$ & \\
P4 & $6,5 \pm 0,2^{\mathrm{b}}$ & \\
\hline Ket: ${ }^{1)}$ komposisi kaldu kepala udang, tepun g tapioka dan bubur Sargasum sp. berturut-turut: 90:10:0 \% (P1), 90:2:8 \% (P2), 90:4:6 \\
\% (P3), dan 90:6:4 \% (P4); DMRT0,05: $2=475,3=0,494,4=0,504$
\end{tabular}

Tabel 6. Rerata hasil penilaian hedonik pada parameter tekstur petis udang

\begin{tabular}{cccc}
\hline Perlakuan & Rerata \pm SD & Kategori & DMRT $_{0.05}$ \\
\hline P1 & $3,5 \pm 0,1^{\mathrm{b}}$ & Suka & \\
P2 & $3,3 \pm 0,1^{\mathrm{a}}$ & Suka & $2=0,176$ \\
P3 & $4,2 \pm 0,2^{\mathrm{b}}$ & Suka & $3=0,183$ \\
P4 & $3,7 \pm 0,1^{\mathrm{b}}$ & Suka & $4=0,187$ \\
\hline
\end{tabular}

Ket: ${ }^{1)}$ komposisi kaldu kepala udang, tepung tapioka dan bubur Sargasum sp. berturut-turut: 90:10:0 \% (P1), 90:2:8 \% (P2), 90:4:6 \% (P3), dan 90:6:4 \% (P4); DMRTo,05: 2 =0,176, 3 =0,183, 4 = 0,187

Tekstur adalah suatu yang dapat diamati dengan indra peraba, baik tekstur, permukaan, kekenyalan dan sebagainya. (Asyik et al., 2017). Hasil uji deskriptif terhadap kriteria tekstur produk petis udang menunjukkan nilai rerata tertinggi pada perlakuan $\mathrm{P} 1$ sebesar 7,3 kriteria kental homogen dan lembut. Nilai terendah terletak pada perlakuan P2 sebesar 5,9 dengan kriteria agak kental kurang homogen kasar. 
Berbeda dengan hasil nilai rerata pada penilaian hedonik (Tabel 6) menunjukkan bahwa nilai rerata tertinggi pada perlakuan $\mathrm{P} 3$ sebesar 4,2 dan nilai terendeh terdapat pada perlakuan $\mathrm{P} 2$ dengan nilai 3,3.

Hasil tekstur petis penelitian ini berbeda dengan tekstur petis udang dengan penambahan tepung arang tempurung kelapa 0,05\% penelitian Suhanda
(2013), yaitu dengan kriteria spesifik petis udang kurang. Peningkatan kekentalan dan kepadatans petis udang dapat terjadi karena adanya adanya kandungan amilopektin yang tinggi. Amilopektin memiliki rantai cabang yang panjang dan memiliki kecenderungan yang kuat untuk membentuk gel (Fajita, 2016).

\section{d. Rasa}

Tabel 7. Rerata hasil penilaian deskriptif pada parameter rasa petis udang

\begin{tabular}{ccc}
\hline Perlakuan & Rerata & Kategori \\
\hline P1 & $7,3 \pm 0,2^{\mathrm{b}}$ & 7 = rasa udang dominan manis dan asin \\
P2 & $6,0 \pm 0,4^{\mathrm{a}}$ & cukup \\
P3 & $7,4 \pm 0,1^{\mathrm{b}}$ & 6 = rasa udang sedikit berkurang manis \\
P4 & $7,0 \pm 0,2^{\mathrm{b}}$ & atau asin kurang
\end{tabular}

Ket: 1) komposisi kaldu kepala udang, tepung tapioka dan bubur Sargasum sp. berturut-turut: 90:10:0 \% (P1), 90:2:8 \% (P2), 90:4:6 $\%$ (P3), dan 90:6:4 \% (P4); DMRT $0,05: 2=0,365,3=0,379,4=0,388$

Tabel 8. Rerata hasil penilaian hedonik pada parameter rasa petis udang

\begin{tabular}{cccc}
\hline Perlakuan & Rerata \pm SD & Kategori & DMRT 0.05 \\
\hline P1 & $4,1 \pm 0,1^{\mathrm{a}}$ & Suka & \\
P2 & $3,5 \pm 0,2^{\mathrm{a}}$ & Suka & $2=0,283$ \\
P3 & $4,5 \pm 0,2^{\mathrm{a}}$ & Sangat Suka & $3=0,294$ \\
P4 & $3,7 \pm 0,1^{\mathrm{b}}$ & Suka & $4=0,301$ \\
\hline
\end{tabular}

Ket: 1) komposisi kaldu kepala udang, tepung tapioka dan bubur Sargasum sp. berturut-turut: 90:10:0 \% (P1), 90:2:8 \% (P2), 90:4:6 $\%$ (P3), dan 90:6:4 \% (P4); DMRT0,05: $2=0,283,3=0,294,4=0,301$

Rasa merupakan faktor yang sangat menentukan keputusan akhir konsumen untuk menerima atau menolak suatu bahan pangan dan olahannya (Fakhrudin, 2009). Hasill uji sensori analisis ragam terhadap kriteria tekstur petis udang menunjukkan nilai rerata tertinggi pada perlakuan P3 sebesar 7,4 dengan kriteria rasa udang dominan manis dan asin cukup. Nilai rerata terendah terletak pada perlakuan P2 sebesar 6,0 dengan kriteria rasa udang sedikit berkurang, manis atau asin kurang. Hasil penilaian skala hedonik (Tabel 8) menunjukkan bahwa peningkatan konsentrasi Sargassum sp. berbanding terbalik dengan tingkat kesukaan panelis terhadap rasa petis udang. Perlakun P3 dapat menghasilkan rasa yang seimbang, sehingga rasa khas pati tepung tidak terlalu tampak. Penelitian ini sesuai dengan penelitian Apriliani (2019), yaitu petis kepala udang dengan penambahan tepung maizena $6 \mathrm{~g}$ dengan kategori sangat suka dan kriteria rasa udang dominan manis dan asin cukup. Rasa yang terbentuk pada petis merupakan bentuk degradasi asam amino yang mengalami perubahan susunannya menjadi senyawa aldehid. 


\section{Uji Proksimat}

Tabel 9. Hasil analisis kandungan proksimat petis kepala udang dengan penambahan rumput laut Sargassum sp.

\begin{tabular}{|c|c|c|c|}
\hline \multirow{2}{*}{ Parameter Pengujian } & \multirow{2}{*}{$\begin{array}{l}\text { Persyaratan SNI 01- } \\
23346-2006\end{array}$} & \multicolumn{2}{|c|}{ Nama Sampel } \\
\hline & & P1 & P3 \\
\hline Kadar Air (\%) & $20-30$ & 23,89 & 29,86 \\
\hline Kadar Abu (\%) & Maks 8,0 & 2,83 & 5,66 \\
\hline Kadar Protein (\%) & Min. 10 & 14,56 & 16,79 \\
\hline Kadar Lemak (\%) & - & 0,25 & 0,21 \\
\hline Kadar Karbohodrat (\%) & Maks $40 \%$ & 57,71 & 46,26 \\
\hline Serat Kasar (\%) & & 0,76 & 1,12 \\
\hline
\end{tabular}

Keterangan: P1 (Kaldu kepala udang 90\%: Tepung tapioka 10\%: Sargassum sp. 0\%), P3 (Kaldu kepala udang 90\%: Tepung tapioka 4\%: Sargassum sp. 6\%)

\section{a. Kadar Air}

Kadar air merupakan salah satu karakteristik yang sangat penting pada bahan pangan, karena air dapat mempengaruhi kenampakan, tekstur dan cita rasa pada bahan pangan. Menurut BSN (2006), petis udang maksimal $20-30 \%$. Hasil uji proksimat petis kepala udang Vaname dengan variasi penggunaan Sargassum sp. dan tepung tapioka menunjukan nilai rerata tertinggi pada perlakuan P3 dengan nilai $29,89 \%$ sedangkan nilai terendah terdapat pada perlakuan P1 dengan nilai 23,86\%. Namun demikian kadar air kedua perlakuan masih memenuhi standar SNI 1-2346-2006. Tingginya kandungan air pada perlakuan P3 diduga karena penambahan rumput laut Sargassum sp. Kadar air pada rumput laut coklat pada pengeringan dengan menggunakan matahari, yang kurang dari 32\% (Masduqi et al., 2014). Semakin tinggi konsentrasi penambahan Sargassum sp. maka semakin tinggi kadar air petis yang dihasilkan.

Suhanda (2013), melaporkan hasil yang berbeda dalam pembuatan petis kepala udang dengan penambahan tepung arang tempurung kelapa 0,05\% diperoleh kadar air $19,28 \%$, petis tanpa penambahan tepung arang memiliki kadar air tertinggi yaitu $20,24 \%$. Rendahnya kadar air diduga karena penambahan tepung arang tempurung kelapa. Menurut Hindarso (2008), polaritas dari karbon aktif akan mampu menyerap air. Selain itu juga arang tempurung kelapa karbon aktifnya yang cukup tinggi sekitar 18,80\% sehingga daya serapnya juga tinggi (Danan, 2008).

\section{b. Kadar Abu}

Kadar abu merupakan jumlah kandungan bahan-bahan anorganik berupa garam mineral di dalam produk yaitu petis (Erika, 2010). Menurut BSN (2006) petis udang kadar abu maksimal 8,0\%. Hasil uji proksimat petis kepala udang Vaname dengan penggunaan Sargassum sp. dan tepung tapioka menunjukan nilai rerata tertinggi pada perlakuan P3 dengan nilai $5,66 \%$. Nilai terendah terdapat pada perlakuan P1 dengan nilai 2,83\%. Kadar abu kedua perlakuan masih memenuhi standar SNI 1-2346-2006. Tingginya kadar abu pada perlakuan P3 diduga adanya penambahan Sargassum sp. pada petis kepala udang. Sargassum sp. mengandung garamgaram mineral. Menurut Atmaja et al. (1996), Sargassum sp. mengandung mineral seperti kalsium $420 \mathrm{mg} / 100 \mathrm{~g}$ berat kering. Suhanda (2013), melaporkan dalam pembuatan petis kepala udang dengan tanpa penambahan tepung arang memiliki kadar abu sebesar $7,44 \%$ dan penambahan tepung arang sekam padi 0,05\% mengalami peningktan yaitu sebesar 9,01\%. Kandungan abu yang terdapat pada arang sekam padi, juga terdapat kandungan mineral lain yang membentuk abu (Danan, 2008).

\section{c. Kadar Lemak}

Lemak merupakan zat makanan yang sangat penting bagi tubuh karena lemak akan menghasilkan energi bagi tubuh. Pada SNI tentang petis udang, standar kadar lemak tidak disebutkan. Mungkin 
karena jumlahnya dianggap kurang signifikan atau mungkin tidak dianggap berpengaruh signifingkan pada mutu petis udang. Hasil uji proksimat petis kepala udang Vanname dengan penggunaan Sargassum sp. dan tepung tapioka menunjukan nilai rerata tertinggi pada perlakuan $\mathrm{P} 1$ dengan nilai $0,25 \%$. Sedangkan nilai terendah terdapat pada perlakuan P3 dengan nilai $0,21 \%$. Rendahnya kadar lemak pada perlakuan P3 diduga karena rendahnya kadar lemak pada Sargassum sp. dapat menurunkan kadar lemak petis udang. Fleurence (1993), mengemukakan bahwa rumput laut mengandung sangat sedikit lemak, yaitu $13 \%$ dari berat kering. Perbedaan kadar lemak ini kemungkinan disebabkan adanya perbedaan pemilihan komposisi dan bahan baku pada petis udang (Winarno, 1994).

\section{d. Kadar Protein}

Protein merupakan suatu zat makanan yang sangat penting bagi tubuh manusia, karena protein berfungsi sebagai bahan bakar, bahan pengatur dan pembangun (Winarno, 1991). Menurut BSN (2006) petis udang kadar protein minimal $10 \%$. Hasil uji proksimat petis kepala udang Vaname dengan penggunaan Sargassum sp. dan tepung tapioka menunjukan nilai rerata tertinggi pada perlakuan P3 dengan nilai $16,79 \%$. Sedangkan nilai terendah terdapat pada perlakuan P1 dengan nilai $14,56 \%$. Kadar protein kedua perlakuan masih memenuhi standar SNI 1-2346-2006. Tingginya kadar protein pada perlakuan P3 diduga karena penambahan Sargassum sp. sesuai dengan pendapat Burtin (2003), bahwa rumput laut coklat mengandung protein sebesar 3-9\% dari berat basah. Dalam kosentrasi tertentu, dapat mempengaruhi kadar protein petis. Kadar air yang terkandung dalam Sargassum sp. mempengaruhi kandungan protein petis.

Suhanda (2013), melaporkan dalam pembuatan petis kepala udang dengan penambahan tepung arang sekam padi 0,05\% memiliki kadar abu sebesar 19,89\% dan penambahan tepung arang tempurung kelapa 0,05\% mengalami peningktan yaitu sebesar $26,60 \%$. Tingginya kadar protein karena penambahan tepung arang tempurung kelapa. Arang tempurung kelapa mengandung karbon aktif yang tinggi yaitu 18,80\%. Menurut Siregar et al. (2002) karbon aktif berfungsi sebagai absorben (penyerap) salah satunya adalah air dari udara lembab maupun dari bahan, dimana dengan semakin sedikitnya kadar air, maka kadar protein akan semakin tinggi.

\section{e. Kadar karbohidrat}

Karbohidrat merupakan salah satu kandungan gizi yang sangat dibutuhkan oleh tubuh dan juga termasuk nilai gizi pokok sumber energi yang dikonsumsi oleh masyarakat (Argo et al., 2018). Menurut BSN (2006) bahwa kadar karbohidrat petis udang maksimal 40\%. Hasil perhitungan Carbohydrete by Difference, kadar karbohidrat petis udang menunjukan nilai rerata tertinggi pada perlakuan P1 sebesar $57,71 \%$ Sedangkan nilai terendah terdapat pada perlakuan P3 dengan nilai $46,26 \%$. Namun demikian kadar karbohidrat dalam penelitian ini melebihi standar SNI 1-2346-2006. Tingginya kadar karbohidrat pada perlakuan P1 diduga karena adanya komponen pati pada tepung tapioka. Amilum adalah karbohidrat kompleks yang tidak larut dalam air, dimana pati merupakan polisakarida yang mengandung amilosa dan amilopektin (Sudarmadji, 1996). Menurut Jannah (1993), sumber karbohidrat pada petis udang berasal dari perlakuan gula aren (Arenga pinnata) yang ditambahkan, walaupun cuma sebagai bumbu. Penelitian ini sama dengan penelitian Fajrita (2016) dengan penggunaan tepung tapioka pada petis dapat meningkatkan kadar pati. Penggunaan tepung tapioka sebesar $2 \%$ diperoleh nilai sebesar $42,50 \%$ dan penggunaan tepung tapioka sebanyak $6 \%$ mengalami peningkatan karbohidrat sebesar $43,42 \%$.

\section{f. Kadar Serat Kasar}

Serat merupakan komponen non gizi yang terdiri dari serat makanan (dietry fiber) dan serat kasar (crude fiber). Hasil uji proksimat kadar serat petis udang menunjukan nilai rerata tertinggi pada perlakuan P3 sebesar 1,12\%. Sedangkan nilai terendah kadar serat terdapat pada perlakuan P1 dengan nilai 0,76\%. Karena belum ada standar kadar serat pada SNI, serat kasar petis hanya dapat dibandingkan dengan bahan lain. Meningkatnya kandungan serat diduga karena adanya sisa - sisa 
ampas dari Sargassum sp. yang sukar hancur. kadar serat Sargassum sp. memiliki nilai rerata 40,99\%51,85\% (Yuniarti, 2011). Kalsum 2019), melaporkan penambahan Sargassum sp. pada selai ubi jalar ungu, kadar serat mengalami peningkatan dimana penambahan Sargassum sp. $30 \%$ pada selai diperoleh kadar serat $1,30 \%$ dan penambahan kosentrasi Sargassum sp. sebanyak 45\% mengalami peningktan menjadi $1,44 \%$.

\section{KESIMPULAN}

1. Terdapat pengaruh nyata terhadap nilai sensori kenampakan, aroma, tekstur dan rasa pada produk petis kepala udang Vaname dengan variasi penambahan tepung tapioka dan Sargassum sp.

2. Terdapat perbedaan nilai proksimat yang ada pada setiap perlakuan petis kepala udang vanname dengan penggunaan tepung tapioka dan Sargassum sp.. Nilai kadar air yaitu berkisar 23,89-29,86\%, kadar abu berkisar 2,83-5,66\%, kadar protein berkisar 14,56-16,79\%, kadar lemak berkisar 0,25\%-0,21\% dan kadar karbohidrat berkisar $57,71 \%-46,26 \%$ dan kadar serat 0,76 $1,12 \%$.

\section{DAFTAR PUSTAKA}

Anwar A. 2018. Studi Mutu Petis Udang Rebon (Acetes Erythraeus) Dengan Penambahan Jumlah Garam Yang Berbeda. Skripsi. Universitas Riau Pekanbaru.

Apriliani P. 2019. Berbagai Konsentrasi Tepung Maizena Terhadap Sifat Fisikokimia dan Organoleptik Petis Udang. SKRIPSI. Universitas Semarang.

Argo, B. D., Yusron, S. dan Alvian, B.I. 2018. Analisis Kandungan Abon Ikan Patin (Pangsius Pangsius) dengan Treatment Alat "Spinner Pulling Oil" sebagai Pengentas Minyak Otomatis. Jurnal Keteknikkan Pertanian Tropis dan Biosistem. Vol. 6 No. 1, Hal. 52-62.

Astawan, M. 2004. Petis si Hitam Lezat Bergizi. http://www.kompas.com/kesehatan/news/se nior/gizi.htm. 25 Agustus 2019

Asyik, N., Hermanto dan Hamsin, L. 2017. Kajian Subtitusi Rumput Laut (Eucheuma cottonii) dan Kacang Hijau (Phaseolus eureus) dalam Pembuatan Dodol Terhadap Sifat Organoleptik dan Nilai Gizi. Prosiding Seminar Nasional FKPT-TPI 20-21 September 2017. Kendari. 1996. Pengenalan Jenis - jenis Rumput Laut. Jakarta: Puslitbang Oseanologi LIPI.

BSN [Badan Standarisasi Nasional]. 2006. Petis Udang. Dewan Standarisasi Nasional.
Burtin, P. 2003. Nutritional value of seaweed. Journal of Agricultural Food Chemistry 2 (4):1-6.

Danan, Eko. S, 2008. Pengolahan Limbah Pertanian menjadi Biobriket sebagai salah satu Bahan Bakar Alternatif ", Laporan penelitian, UNS.

Fajita I. Khempaka, S., Koh, K., Karasawa Y. 2016. Tingkat Kesukaan Petis dari Cairan Hasil Pemindangan Bandeng dengan Penambahan Tepung Tapioka yang berbeda. Jurnal Perikanan Kelautan. 43(3):250-24.

Fakhrudin, A. 2009. Pemanfaatan Air Rebusan Kupang Putih (Corbula faba Hinds) untuk Pengolahan Petis dengan Penambahan Berbagai Pati-Patian. Skripsi. Fakultas Perikanan dan Ilmu Kelautan, Institut Pertanian Bogor. Bogor.

Fleurence, J. 1999. Seaweed proteins: biochemical, nutritional aspects and potential uses. Review of Trends in Food Science and Technology 10:25-28.

Firdaus, Masdiana, Agus Susilo. 2016. Kualitas Petis Daging dengan Sumber Pati Berbeda. Jurnal Ilmu dan Teknologi Hasil Ternak. 11(1): 8-21

Garmo D, E.D, G. Sullivan and J . R. Canada. 1984. Egineering Economis. Mc Millan Publishing Company. New York. 
Gernat, A.G. 2001. The Effect of Using Different Levels of Shrimp Meal in Laying Hen Diets. Poultry Science 80: 633-636

Hafiz M. 2009. Karakteristik dan Bentuk Olahan Udang Vaname [Laporan Penelitian]. Ipb. Bogor.

Hindarso. 2008, Pembuatan Arang Aktif Dari Serbuk Gergajian. Buletin Penelitian Hasil Hutan Forest Products Research Bulletin 14 (8): 308320.

Jannah HA. 1993. Upaya Meningkatkan Daya Simpan Ubi Kayu Segar di Pedesaan. Program Pasca Sarjana.Universitas Brawijaya Malang. $20 \mathrm{~h}$.

Kadi A. 2005. Kesesuaian Perairan Teluk Klabat Pulau Bangka untuk Usaha Budidaya Rumput Laut. Jurnal Oseana Vol. 30: Hal. 4-7.

Kalsum U.2019. Pengaruh Penambahan Eucheuma Cottonii dan Sargassum sp. Terhadap Komposisi Kimia, Aktivitas Antioksidan Serta Sifat Sensori Selai Ubi Jalar Ungu (Ipomoea Batatas Poir). Skripsi. Universitas Halu Oleo.

Kartika, Pudji, H., Wahyu, S. 1988. Pedoman Uji Indrawi Bahan Pangan. UGM Press. Yogyakarta.

Khempaka, S., K. Koh and Y. Karasawa. 2006. Effect of shrimp meal on growth performance and digestibility in growing broiler. J. Puoltry Sci., 43: $250-254$.

Masduqi AF. 2014. Efek Metode Pengeringan Terhadap Kandungan Bahan Kimia dalam Rumput Laut Sargassum Polycystrum. Buletin Anatomi dan Fisiologi Vol. XXII. (1): 1-9.

Muhklisani. 2018. Efektifitas Alga Coklat (Sargassum sp.) Sebagai Pakan Kosentrat Terhadap Lingkar Scrotum Sapi Bali. Skripsi. Fakultas Sains dan Teknologi Universitas Islami Alaluddin Makassar. Makassar.

Pratiwi N, dan Rahman. 2017. Komposisi Kimia pada Tepung Kulit dan Kepala Udang Vaname (Litopenaeus Vannamei). Jurnal Komposisi Kimia Pada Tepung Kulit dan Kepala Udang Vaname (Litopenaeus Vannamei) Universitas Riau.

Purwanti, A. 2014. Evaluasi Proses Pengolahan Limbah Kulit Udang untuk Meningkatkan Mutu Kitosan yang Dihasilkan. Jurnal Teknologi, Volume 7 Nomor 1: 83-90.

Rochima E. 2015. Karakteristik Kimiawi dan Organoleptik Pempek dengan Penambahan
Tepung Tulang Ikan Mas asal Waduk Cirata. Jurnal Aquatika. Vol XI (1):79-86.

Rusmono, M. 1983. Mempelajari Pengaruh Derajat Kehalusan Pulp dan Jumlah Air Pengekstrak Terhadap Rendemen dan Mutu Tapioka. Skripsi. Fakultas Teknologi Pertanian Institut Pertanian Bogor, Bogor.

Saleh MR, Abdillah, Suerman E, Basmal J, Indriati N. 1994. Pengaruh Suhu, Waktu dan Kosentrasi Pelarut Pada Ekstraksi Kitosan dari Limbah Pengolahan Udang Beku Terhadap Beberapa Parameter Mutu Kitosan. Jurnal Pasca Panen Perikanan 81:30;43.

Siregar, R. Karnila, M. dan Sukmiwati. 2017. Ekstraksi Senyawa Fenolik dan Kandungan Kimia pada Rumput Laut Coklat (Sargassum sp). Fakultas Perikanan dan Kelautan Universitas Riau Pekanbaru.

Sudarmadji, S., B. Haryono, dan Suhardi. 1996. Prosedur Analisa untuk Bahan Makanan dan Pertanian. Penerbit Liberty, Yogyakarta.

Suhanda, dan Purnomo. 2013. Perbaikan Kualitas

Petis Kepala Udang Windu (Penaeus Monodon) dengan Penambahan Tepung Arang Kayu Galam (Melaleuca Cajuputi Powell), Sekam Padi (Oryza Sativa L) dan Tempurung Kelapa (Cocos Nucifera). Fish Scientiae. 4(6):114-130.

Suprapti, L. 2001. Teknologi Tepat Guna Membuat Petis. Kanisius. Jakarta Journal of Marine and Coastal Science, 1(1), 53 - 60, 2012.

Winarno. 1991. Kimia Pangan dan Gizi. PT. Gramedia Pustaka. Jakarta. 1996. Kimia Pangan dan Gizi. Edisi Terbaru. Gramedia Pustaka Utama. Jakarta.

Yunizal. 2004. Teknologi Pengolahan Alginat. Pusat Riset Pengolahan Produk dan Sosial Ekonomi Kelautan dan Perikanan : Jakarta. 